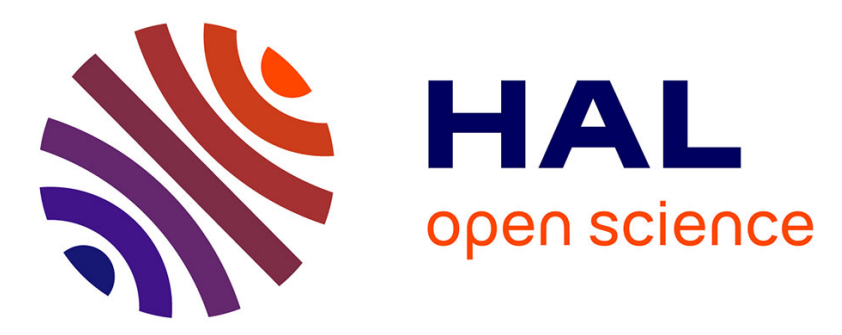

\title{
Structure of Stockmen Collaboration Networks Under Two Contrasting Touristic Regimes in the Spanish Central Pyrenees
}

Hugo Saiz, Maite Gartzia, Paz Errea, Federico Fillat, Concepción L. Alados

\section{- To cite this version:}

Hugo Saiz, Maite Gartzia, Paz Errea, Federico Fillat, Concepción L. Alados. Structure of Stockmen Collaboration Networks Under Two Contrasting Touristic Regimes in the Spanish Central Pyrenees. Rangeland Ecology and Management, 2017, 70 (3), pp.281-289. 10.1016/j.rama.2016.09.007 . hal01532255

HAL Id: hal-01532255

https://hal-univ-rennes1.archives-ouvertes.fr/hal-01532255

Submitted on 12 Oct 2017

HAL is a multi-disciplinary open access archive for the deposit and dissemination of scientific research documents, whether they are published or not. The documents may come from teaching and research institutions in France or abroad, or from public or private research centers.
L'archive ouverte pluridisciplinaire HAL, est destinée au dépôt et à la diffusion de documents scientifiques de niveau recherche, publiés ou non, émanant des établissements d'enseignement et de recherche français ou étrangers, des laboratoires publics ou privés. 
1 Title: Structure of stockmen collaboration networks under two contrasting touristic

2 regimes in the Spanish Central Pyrenees.

3 Authors: Hugo Saiz*a,b,c ${ }_{a}$, Maite Gartzia $a_{d}$, Paz Errea $_{a}$, Federico Fillat ${ }_{d}$, Concepción L.

$4 \quad$ Alados $_{\mathrm{a}}$

5 Affiliations: a Instituto Pirenaico de Ecología (IPE) - CSIC Campus de Aula Dei, Avda.

6 Montañana, 1005. 50059 Zaragoza (Spain).

7 b UMR 6553 Ecobio, CNRS - University of Rennes 1, Avenue du Général Leclerc.

$8 \quad 35042$ Rennes Cedex (France).

9 c Departamento de Biología y Geología, Física y Química Inorgánica, Universidad Rey

10 Juan Carlos, C/ Tulipán s/n. 28933 Móstoles (Spain).

11 d Instituto Pirenaico de Ecología (IPE) - CSIC Campus de Jaca, Avda. Nuestra Señora

12 de la Victoria, s/n. 22700 Jaca, Huesca (Spain).

$13 *$ Corresponding author: saizhugo@gmail.com 
15 Abstract

16 Ecosystem management is a difficult task because it must conciliate the ecological,

17 economic, and social dimensions of socio-ecological systems. In those systems, the

18 action of any single component can have an effect on the others, and result in a critical

19 impact on the organization of the entire system. This study examined the collaboration

20 networks among stockmen within two traditionally agro-pastoral regions in the Spanish

21 Central Pyrenees which in the las 30 years included touristic activities: one under the

22 influence of a National Park and centered on ecotourism, and the other in a region

23 where there are ski resorts and local stockmen have turned to snow tourism. Our

24 hypotheses were that economic regime affects the structure of the networks, and the

25 type of collaboration (e.g. for economic reasons) influences the collaborations among stockmen. We built stockmen collaboration networks by connecting breeders within the same pastoral partnerships, and calculated the importance of collaborations (links density), the occurrence of collaborative subgroups (network modularity), and the existence of collaborations between stockmen in different regions (Krackhardt Ratio). In addition, we identified the distribution of links among types of pastoral partnerships. The network under the influence of the National Park presented higher link density and modularity than did the network influenced by ski resorts, where the presence of nonlocal stockmen is higher. Furthermore, economic partnerships played a major role connecting stockmen. In the study area, differences in the collaboration networks between the two regions suggest that changes in the economic trend in the last 30 years has influenced the collaborative structure of the stockmen. We discuss possible reasons behind these differences and propose some recommendations which could help to strengthen the collaborative bounds between stockmen in the area. 
39 Keywords: Agro-pastoral practices, Collaboration networks, Ordesa-Monte Perdido

40 National Park, Socioeconomic systems, Ski resorts. 
43 Ecosystem conservation is one of the most important challenges of our time. Global 44 change driven by human activities has altered the natural balance and modified Earth 45 processes significantly (Rockström et al., 2009). Those changes have created several 46 threats to the preservation of ecosystems including global warming and biodiversity 47 loss, which are among the most important issues that governments must face to preserve 48 the ecological value of the environment (Sala et al., 2000; Vitousek, 1994; Vitousek et al., 1997). However, finding a balance between the conservation of ecosystems,

50 economic development and the preservation of social values (i.e. sustainable

51 development, Hopwood et al., 2005) can be difficult. Ecosystem management covers

52 only one part of social-economical systems (SES), which combine ecological, economic, and social dimensions of human systems (Millenium Ecosystems Assessment, 2005; Ostrom, 2009). In SES, an effect on any single component can spread to the others and have a significant impact on the entire organization of the system (Holling, 2001; Young et al., 2006). Thus, to develop more effective conservation strategies, all different dimensions of SES have to be assessed simultaneously (Fiksel, 2006). Particularly, in recent times the importance of the social dimension to address the resilience of SES has been highlighted (Berkes and Ross, 2013; Davidson, 2010). For instance, considering the collaborative structure among the

61 inhabitants in SES is central for the system resilience, as differences in the social

62 organization of the system can have significant effects on the success of management 63 practices (Berkes et al., 2000). 
Management practices are particularly important in mountainous regions. In mountain areas, human activities have led to the development of a wide variety of ecosystems that are nowadays considered biodiversity hotspots (Korner and Spehn, 2002; Lomolino, 2001) and whose environmental value is recognized (mountain ecosystems are included within the European Habitat Conservation Strategy, Consejo de las Comunidades Europeas, 1992). Furthermore, those areas have been inhabited for centuries and are presented as examples of sustainable SES that preserve traditional economic activities, mainly agro-pastoral practices; together with the ecological value of the ecosystem (Jodha et al., 1992). For example, in the Spanish Central Pyrenees, the persistence of traditional pastoral habits such as transhumance (i.e. periodic movement of livestock between summer and winter pastures) led to the development of singular plant communities that have both high biodiversity and productivity (Caballero et al., 2011; Ruiz and Ruiz, 1986). Thus, traditional mountain human systems are good examples of sustainable development, where ecological, economic, and social dimensions of the SES are balanced.

In Europe, however, industrial development near cities at the beginning of the 20th

Century led to massive migration from rural to urban areas (Alados et al., 2014; Mather, 2001; Pinilla et al., 2008). This dramatic reduction in human labor had a profound impact on mountain SES and, especially, on the conservation of mountain pastures. In Spanish Central Pyrenees land abandonment and the loss of sustainable pastoral practices have reduced pasture area due to changes in land use (García-Ruiz et al., 1996; Gartzia et al., 2016b, 2014) and 'shrub encroachment' (i.e. increase in the density of local shrubs in pastures to the detriment of herbs and grasses, Komac et al., 2011; Van Auken, 2000). For example, the substitution of pastures by shrublands and forests has been associated to the decrease in livestock numbers in the area (Gartzia et al., 2014). In 
addition, the loss of mountain pastures might be accelerated in near future as they are among the most vulnerable habitats to global climate change (Huber et al., 2006).

Livestock management is one of the main factors responsible for maintaining the ecological value of mountain pastures (Kohler et al., 2004; Zervas, 1998). Livestock grazing influences the growth of the consumed plants, modifies species cover, and changes the composition and structure of plant communities (Milchunas and Lauenroth, 1993; Van Auken, 2000). Furthermore, pastoral ecosystems have been recognized as important providers of ecosystem services (Oteros-Rozas et al., 2013). For example, livestock grazing can increase the productivity of an ecosystem, and transforms a dispersed, low-energy resource (grass) into a concentrated, high-energy resource (livestock meat, Frank et al., 1998). In addition, pastoral activities also help to preserve and transmit traditional local knowledge in mountain SES (e.g. location of water points and grazing paths, regulation of grazing intensities, Hassanein and Kloppenburg, 1995), which helps to accelerate the reorganization of the system after major disturbances (Berkes et al., 2008). Therefore, to preserve mountain pastures and their associated ecosystem services, the conservation of sustainable agro-pastoral activities is essential.

Traditionally, in the Spanish Pyrenees livestock production has involved a communal grazing system in which stockmen collaborate to expand grazing pastures and to preserve their pastoral value (Caballero et al., 2011). Today, this collaborative structure has led to the creation of different livestock partnerships whose duties include from economic to sanitary tasks (e.g. optimize the marketing of products, obtain quality designations for the livestock; or manage veterinary exams, Confederación de Cooperativas Agrarias de España, 2002). Remarkably, the implementation of Common Agricultural Policy (CAP, Consejo Europeo, 2005) has led in recent times to the apparition of several partnerships specialized in maximizing the capture of subsidies 
114 (García-Martínez et al., 2009; Veysset et al., 2005). However, changes in mountain SES as depopulation and the reduction in agro-pastoral practices might modify this collaborative system and, ultimately, influence the viability of mountain pastures. Thus, economic and social dimensions of traditional mountain SES have to be reconciled to

118 preserve the ecological value of mountain pastures.

119 In this study, we evaluate the collaborative structure of stockmen in two regions in Spanish Central Pyrenees. This mountainous area has been traditionally driven by agro-

121 pastoral activities, but with the decline of livestock in recent times, inhabitants have supplemented livestock management with other economic activities associated to tourism. One region has supplemented agro-pastoral practices with ecotourism activities under the influence of a National Park. On the other hand, the other region has incorporated snow tourism activities organized around the development of big ski resorts. We studied the collaborative structure in the area through the analysis of their stockmen collaboration networks (SCN). In these networks, stockmen connect among them considering the different economic and cultural partnerships they belonged to. We hypothesize that the analysis of the SCN unveils valuable information about the organization of stockmen in our SES. For example, differences in the current economic Spanish Central Pyrenees. 
The study was conducted in the Central Pyrenees within the province of Huesca in northern Spain. The study area lies within the alpine mountain range (sensu, the zone above $1500 \mathrm{~m}$, Fillat et al., 2012) with a maximum elevation of $3340 \mathrm{~m}$. The climate is heterogeneous and strongly influenced by elevation, ranging from alpine in mountain grasslands to sub-Mediterranean at low elevations. Average annual temperature ranges from $5^{\circ} \mathrm{C}$ (Goriz Refuge at $2200 \mathrm{~m}$, data from 1976 to 2005 ) to $12.4^{\circ} \mathrm{C}$ (Salinas de Bielsa at $760 \mathrm{~m}$, data from 1961-1967) and average annual precipitation ranges from $1657 \mathrm{~mm}$ (Goriz) to $1307 \mathrm{~mm}$ (Salinas de Bielsa). Historically, grazing activities, which have involved moving livestock from mountain grasslands in summer to the Middle Ebro valley in winter, have driven the local economy (Caballero et al., 2011; Daumas, 1976). However, at the beginning of 20th Century urban development led to a rural depopulation in the area resulting in a reduction of grazing activity and the substitution of pastures and cultivated areas by shrublands and forests (Alados et al., 2014; GarcíaRuiz et al., 1996; Lasanta and Vicente-Serrano, 2007)

We selected two regions in the Spanish Central Pyrenees: Sobrarbe and Alto Gállego counties (Figure 1). Although both regions differ in their population densities (Table 1), their population trends in the 20th Century have been similar (strong decrease until 1980s, when population stabilized, Alados et al., 2014). Furthermore, both regions have experienced the same changes in agro-pastoral activities, with a substitution of sheep livestock by cattle (sheep livestock decreased from $1.4 \mathrm{ind} / \mathrm{ha}$ in 1940 to $0.2 \mathrm{ind} / \mathrm{ha}$ in 2000, while cattle increased from 0.05 ind/ha to 0.14. Data from Archivo Histórico de Huesca and Delegación Provincial de Huesca); principally because the cost of managing cattle is smaller (in the study area, livestock can reach the most remote pastures while cattle is concentrated in the most accessible ones, Gartzia et al., 2016a). Together with changes in shepherding, in recent times stockmen in both regions have supplemented 
pastoral practices with other sources of income mostly linked to services sector (Table 1). However, these sources differed between regions.

165 On one hand, Sobrarbe includes six municipalities (Torla, Broto, Fanlo, Puertolas, Tella-Sin and Bielsa) encompassing the area in and around Ordesa-Monte Perdido National Park (OMPNP, Figure 1). Ordesa-Monte Perdido National Park was created in 1918 and expanded to its current limits in 1982 (15,608 ha). The presence of OMPNP has induced the rise of ecotourism in recent years, resulting in the development of campsites and rural houses (Table 1). On the other hand, Alto Gállego includes five municipalities (Sallent del Gállego, Panticosa, Hoz de Jaca, Biescas, and Yésero) which comprise two ski resorts (Formigal and Panticosa, Figure 1). In the Central Pyrenees, between 1965 and 1976, five alpine ski resorts and associated tourist infrastructures were built, which led to significant changes in the population and pastoral activities in the area (Marín-Yaseli and Lasanta, 2003). Specifically, in this region the development of snow tourism has led to the increase in the number of apartments and hotels (Table 1). It is important to note that, although the touristic development in both regions is different, the number of beds available in touristic accommodations is similar between them (Table 1). However, the number of new building differs, suggesting differences in the presence of secondary residences between regions (Table 1). Thus, we compared two regions which have experienced different economic shifts in the last 30 years: Sobrarbe, which includes ecotourism under the influence of a National Park (NP); and Alto Gállego, which includes snow tourism under the influence of ski resorts (SKI).

In both regions, we conducted personal interviews to all stockmen who transport their livestock to pastures within the study area. Interviews included questions about the 
stockmen (origin, current residence, age, years spent shepherding in the area, education level), and their thoughts about the current environmental situation in the region (changes in the landscape, land use and pastoral practices). We also recorded all the different partnerships which stockmen belonged to. We identified partnerships as groups of individuals which gather sporadically to pursuit a common interest, and used them as a proxy of local associations of stakeholders which collaborate among them (Olsson et al., 2004). All considered partnerships provided a service directly linked to livestock management, and were categorized in four groups according to their objectives: health partnerships, subsidy partnerships, cooperatives, and others (Table 2). It was possible for each stockman to belong to more than one partnership simultaneously, and for stockmen from different regions to belong to the same partnership. Specifically, within the study area, we identified 194 stockmen and 36 pastoral partnerships.

Using the data from stockmen and their partnerships, we built an $X_{S x P}$ matrix. In the matrix $X$, stockmen $(S)$ are rows and partnerships $(P)$ columns, and $X_{i j}=1$ when stockman $i$ belongs to partnership $j$. Based on $X$, we built stockmen collaboration networks ( $\mathrm{SCN})$, in which a link exists between two stockmen if they belong to the same partnership (sensu, affiliation networks, Borgatti and Halgin, 2011). Although sharing a partnership is not an explicit measure of collaboration, as stockmen in the same partnership have common interests and group together to attain benefits related to agro-pastoral practices, we assumed that partnership sharing is a valid proxy of a collaborative link. Therefore, $\mathrm{SCN}$ was defined as a square matrix $L_{S x S}$ where $l_{i j}$ is the collaboration between stockmen $i$ and $j\left(l_{i j}=\right.$ number of partnership shared by stockmen

$210 i$ and $j)$. The number of links of a stockbreeder $i\left(L_{i}\right)$ is the number of collaborative bounds he has with other stockmen, and the total number of collaborations in the system 
212 is $L$. We built one SCN for stockmen in each region, and another including both regions combined (TSA, total study area: stockmen in NP + stockmen in SKI). We drew the networks with NETDRAW (Analytic Technologies; http://www.analytictech.com/netdraw/netdraw.htm).

216 For each network we calculated isolation, linkage density, modularity and Krackhardt

217 Ratio (Borgatti and Halgin, 2011; Krackhardt and Stern, 1988; Newman, 2006a), definition and abbreviations of indices are included in Table 3). All of those indices are related to the resilience, adaptive and information-spreading capacity of the network, and have significant effects on the robustness of the system (Janssen et al., 2006; Newman, 2006b). For example, indices related to network cohesion (Isolation, Density) and connection between subgroups (Modularity, Krackhardt Ratio) are related to the communication between subgroups within the system (Barnes-Mauthe et al., 2013), which can pose challenges to manage common resources (e.g. low cohesive systems), or can increase the productivity and innovative capacity (e.g. high connectivity between different groups) (Bodin and Crona, 2009). To quantify the significance of the indexes observed in each SCN, we simulated 1000 matrixes setting the number of links per row and column to that of $X_{S x P}$. We built the corresponding $L_{S x S}$ for each simulated matrix and calculated all indices. Real values were significantly different from simulated values if they separated more than 2 standard deviations from the mean of the values from the simulations. We also evaluated differences in the SCN structure of both regions comparing the isolation, number of partnership per stockbreeder $\left(A_{i}\right)$ and the number of links per stockbreeder $\left(L_{i}\right)$. We used a Chi-square test to compare Iso, and a

234 Generalized Linear Model (GLM) to compare $A_{i}$ and $L_{i}$ between regions. All calculus were performed with R (R Development Core TeamTeam, 2014). 
236 We evaluated the effect of the type of partnership on the collaborations among

237 stockmen in two ways. First, we used a Chi-square test to compare the proportion of collaborative bounds among stockmen between the two regions considering the partnerships categories. Second, we used a Generalized Linear Mixed Model (GLMM) to assess the effects of region and partnership category in $A_{i}$ and $L_{i}$. Model included $A_{i}$ and $L_{i}$ as response variables, the interaction between region and type of partnership as an explanatory fixed variable, and stockbreeder identity as an explanatory random variable. In addition, to assess the influence of partnership category on the collaborations within and between regions, we built one individual SCN for each category of partnerships and calculated the Krackhardt Ratio of each network. All comparison tests were performed using $\mathrm{R}$.

\section{Results}

\subsection{Characteristics of stockmen}

Stockmen groups presented similar characteristics in both regions, with most stockmen presenting similar age (more than 40 years) and education level (secondary level). Furthermore, most stockmen came from a family related to shepherding and have carried their livestock to pastures in the area for more than 30 years. We only found significant differences between regions in the origin of stockmen, with more proportion of foreign stockmen in SKI foreign $_{\mathrm{NP}}=2 / 81=0.02$; foreign $_{\mathrm{SKI}}=22 / 113=0.19 ; X^{2}=$ 11.06, $p<0.001)$. All stockmen agreed that in recent times mountain pastures and landscape have changed noticeably (principally, through the substitution of pastures by shrubland and forest). From all stockmen in the study area, nine were not connected to others (sensu, they did not present any collaborative links with others). Connected 
stockmen organized in SCNs that had a big block composed by most of the stockmen, and few stockmen isolated in smalls blocks (Figure 2). Characteristics of the SCNs are presented in Table 4.

\subsection{Network analysis}

Network indices showed that the SCN for the whole study area had higher Iso and $Q$ than expected (Table 5), which suggests that stockmen organized forming close collaborative groups. Focusing on the regions, both networks presented higher densities (D) than expected based on the simulations (Table 5). However, the network in SKI had higher Iso and lower $Q$ than expected, while the network in NP had higher $Q$ than expected. This suggests that in NP there were groups of stockmen who collaborated closely with each other, while in SKI there were not tight collaborative groups. Furthermore, in SKI there were also several stockmen who did not present any collaboration links.

Comparing both regions, SKI had significantly more isolated stockmen $\left(\chi^{2}=4.79, \mathrm{df}=\right.$ $1, p$-value $=0.029)$, and significantly fewer partnerships per stockbreeder and fewer links per stockbreeder than NP (Table 6). This suggests that stockmen established more collaborative associations in the region under the influence of the National Park than in the region with ski resorts. Furthermore, Krackhardt Ratio indicated that most of the collaborative links were between stockmen within the same region (Table 5), which suggests that stockmen preferred to partner with their geographic neighbors.

\section{The effect of type of partnership on the collaborations among stockmen differed} between the two regions $\left(\chi^{2}=1934.38, \mathrm{df}=3\right.$, $\mathrm{p}$-value $\left.<0.001\right)$. Specifically, in NP all four types of partnerships were responsible of establishing collaborations, while in SKI, most of the collaborative links were through health and subsidy partnerships (Figure 3). 
284 Furthermore, type of partnership and region had a significant interaction on the numbers of partnerships per stockbreeder and links per stockbreeder (Table 6). In NP, stockmen were most likely to belong to cooperatives and local partnerships, and had more collaborative links with other stockmen than stockmen in SKI; especially, through health, cooperative and local partnerships (Figure 4). In both regions, collaborations were significantly more concentrated in subsidy partnerships. Krackhardt Ratio indicated that stockmen associated more with others in the same region; independently of the type of partnership $\left(E / I_{\text {sanitary }}=-0.99 ; E / I_{\text {subsidy }}=-0.56 ; E / I_{\text {cooperative }}=-0.97 ; E / I_{\text {local }}\right.$ $=-1$; all real $E / I$ values were significantly lower than the simulations). Among the types of partnerships, the one which connected most stockmen from different regions was the subsidy partnership (had the highest E/I Ratio).

\subsection{Characteristics of Stockmen Collaboration Networks}

In the Central Pyrenees, the analysis of the stockmen collaboration networks (SCN) helped to disentangle the structure of stockbreeder community. In the whole study area, the SCN presented a modular structure in which stockmen organized themselves into close groups, with this groups mainly formed by stockmen habiting within the same region. These collaborative groups can arise for different reasons. On one hand, study area is characterized by the presence of valleys and mountain ranges. The presence of mountain ranges can act as a geographical barrier to migration and cultural transfer between valleys, resulting in the partial isolation of regions within the area and the development of different cultural landscapes (Axelrod, 1997). Therefore, the historical 
and communities highly linked to local identity (Rössler, 2006). On the other hand, in social network analysis, typically, actors preferentially interact with those who are most similar to them (a property called homophily, McPherson et al., 2001) or share common interests (Feld, 1981). In the Spanish Central Pyrenees, stockmen have spent decades organizing the annual use of local pastures (Fernández-Giménez and Fillat, 2012).

Because stockmen usually moved their livestock to the pastures closest to their dwelling, they mostly organized the use of pastures with their neighbors and, consequently, more collaborations appeared. This preference for collaborating with neighbors might explain why, in general, stockmen belong to few associations (in the study area, $50 \%$ of the stockmen belonged to two or less associations).

Considering the two regions, although stockmen communities were similar in age, education and experience in shepherding, we observed contrasting structures in their SCNs. In the region under the influence of the Ordesa-Monte Perdido National Park (OMPNP) and more focused on ecotourism (NP), the network was organized in close collaborative groups and stockmen established high number of collaborations. In the area near OMPNP, stockmen have been sharing pastures for centuries (Sal and Lorente, 2004), with the creation of historical local organizations such as 'Mancomunidad del Valle de Broto' and 'Casa de Ganaderos de Zaragoza' (founded in the 13th Century) to regulate grazing management. The necessity of sharing pastures in the same place has strengthened the interaction bounds, resulting in a very close collaborative system formed by neighbors and pastures partners. This can be seen in the importance of cooperatives and other partnerships in the region (Figure 3 and 4). The existence of these historical organizations is important in the region and they have been presented as important keepers of traditional knowledge in Pyrenees (Fernández-Giménez and Fillat, 2012). Furthermore, in recent times several partnerships have appeared to maximize the 
acquisition of subsidies intended for the maintenance of traditional agro-pastoral practices in the area (related to the presence of a National Park, Gobierno de España, 2007; and Common Agricultural Policy, Consejo Europeo, 2005), which have become the main source of income for stockmen in the area (Fernández-Giménez, 2015; Plieninger, 2006). For example, to defend the interests of livestock owners in the National Park, a specific partnership was formed ("Asociación de Ganaderos del Parque Nacional de Ordesa y Monte Perdido'). This partnership brings together the stockmen who move their herds to the pastures within the Park, and has greatly helped to strengthen the collaborative bounds in the area.

On the other hand, the SCN in the region including snow tourism (SKI) presented several stockmen with no collaborative links and was not organized in groups. In SKI the reduction in sheep and goats has resulted in a significant increase in the amount of ungrazed mountain pastures (García-Ruiz et al., 1996; Lasanta and Vicente-Serrano, 2007). Although the reduction in livestock was widespread in the Pyrenees (including the area within the National Park), the pastures in SKI region have been more attractive because they are easier to manage (e.g., they are accessible by car, have shallow slopes, Gartzia et al., 2016a) and have been highly demanded to develop goods related to snow activities (Marín-Yaseli and Lasanta, 2003). This has resulted in a strong turn from an economy centered in agro-pastoral sector to another more focused on services, which is enhanced in the areas near ski resorts (Marín-Yaseli and Lasanta, 2003). Substitution of agro-pastoral practices by ski tourism is common in mountain areas (Gellrich et al., 2007; Teodoro Lasanta and Vicente-Serrano, 2007) and usually, in farms, different economical activities coexist (Riedel et al., 2007). However, the harmonious coexistence between shepherding and tourism strongly depends in the goals of the local stockmen (Gasson et al., 1993). In general, stockmen in the study area complained 
about the hardness of livestock management compared to other jobs and the lack of replacement by new generations (Fernández-Giménez, 2015). This lack of replacement has caused that in recent times, particularly in the SKI region, non-local stockmen have transported their herds to the region. These newcomers belonged to non-local partnerships before they arrived and so, did not require to join the local ones, resulting in a weakest collaborative structure.

\subsection{Effect of type of partnership in the collaborative structure}

The importance of the type of partnership structuring SCNs showed that, independently of the region considered, most collaborative links were based on economic profit (subsidy partnerships produced the most collaborations, even between stockmen from different regions, Figure 3). Since the implementation of Common Agricultural Policy (CAP) in 1986, subsidies have been the main force shaping the agro-pastoral sector in Spain, particularly replacing sheep farming by cattle (García-Martínez et al., 2009; Plieninger, 2006). Particularly, belonging to partnerships that facilitate the process of receiving funds has been profitable (e.g. partnership help its members to request subsidies properly), and consequently, stockmen prioritize most profitable partnerships over other factors as geographical proximity or neighbors preferences. The involvement of public and private services can help to sustain agro-pastoral systems (Bernués et al., 2003), but is central to identify the main drivers behind the organization of SES to apply efficient management practices.

Network structure has strong implications in the resilience of a system (Bodin and Crona, 2009; Olsson et al., 2004; Tompkins and Adger, 2004). In a system with a modular structure, information transfer from one module to another is difficult, but it might also result in the formation of smaller and more efficient working groups (Janssen 
et al., 2006). In the Spanish Central Pyrenees, stockmen have collaborated with whom they share pastures and coordinated to move their livestock along the year to optimize pastures forage production. Collaborative groups represented by the modules in the network might facilitate the efficient exploitation of pastures, which might help to maintain their ecological and pastoral value. However, most of those small groups were quite closed, which can obstruct the creation of a large-scale collaborative structure.

Studies on adaptive management have suggested that non-modular organizations are more adaptive than modular ones, and they allow the inclusion of external information and the creation and reassembling of links in the system (Aldrich, 1999; Granovetter, 1973). Thus, non-modular organizations respond faster to changes in the external conditions of socio-ecological systems and can evolve to new possible equilibrium states (Holling, 2001). It is possible that the SES in the SKI region is still adapting to the presence of ski resorts, and it will take time before it is known whether this process leads to an equilibrium in which only one between local traditional practices and skirelated sources of incomes dominates, or both activities coexist becoming the main drivers of the economic development in the region.

The collaboration networks used in our study were based on affiliation networks (sensu (Borgatti and Halgin, 2011), and it is important to consider that these networks have limitations. For example, in our study we assumed that stockmen who belonged to the same partnership were collaborating, but this is only a proxy of a real collaboration. For example, almost all of the stockmen belonged to partnerships related to mandatory health controls imposed by Government ( $85 \%$ of stockmen belonged to one health association), which was the result of legal issues rather than truly collaborative bounds. Consequently, we did not find a significant effect of health partnerships between the two regions. Thus, is important to consider the actual contribution of a certain type of 
partnership to the collaborative structure of the system. Another possible limitation involves the transformation from affiliation to stockmen network. An affiliation network indicates which stockman belongs to each of the partnership, but SCN indicates the collaborative links between stockmen (Borgatti and Halgin, 2011). We could have used an affiliation matrix directly to test our hypotheses, but as we were interested in

412 the specific organization among stockmen, we restricted our analyses to SCN. In addition to methodological issues, it is important to consider the effect of other factors on the collaborative structures of both regions. For example, differences in population between regions could influence the collaborative structure (e.g. smaller populations have less potential collaboration opportunities); or differences in pastures availability could require alternative management strategies (e.g. lower pastures availability needs better collaboration among stockmen). Therefore, although differences in touristic activities between our study regions seem the main reason behind the structure of SCN, we cannot exclude other possible causes.

Despite these limitations, our results suggest that differences in current economic trends in the study area might affect the collaborative structure between the inhabitants. In our study area, the collaborative system in the region influenced by the presence of the

424 National Park and ecotourism was characterized by strongly connected groups of 425 stockmen, while in the region turning to ski oriented tourism collaboration was weaker and less organized. Economic factors appeared to be the main reason behind the 427 establishment of collaborations between stockmen, particularly, through partnerships specialized in getting subsidies which gathered most the connections between stockmen

429 from different regions. 
431 The success of environmental management practices depends on a correct assessment of

432 the ecological, economic and social dimensions of the area under consideration (Fiksel, 433 2006), as the action of any dimension can spread to the others ( Holling, 2001; Young et 434 al., 2006). Particularly, in recent times the importance of the social dimension to address 435 the resilience of SES has been highlighted (Berkes and Ross, 2013; Davidson, 2010). A 436 proper understanding of the people living in the communities has been presented as central to include in resilience frameworks (Crane, 2010). For instance, economic changes can alter the social structure of a human community, and hence, modify the environmental management that the community requires (Alados et al., 2014; Isaac et al., 2007); or differences in the social organization of the system can significantly alter the success of management practices (Berkes et al., 2000). Thus, including the social dimension in the study of traditional agro-pastoral SES is essential to improve the management of mountain pastures and avoid unexpected effects on their preservation in the near future.

We suggest that the use of Stockmen Collaboration Networks (SCN) could improve the understanding of the social organization of the inhabitants in a region, helping to improve the implementation of management practices. The application of social networks to unveil the structure of stakeholders and help in the management of SES has been shown to be important in recent times (Barnes-Mauthe et al., 2013; Beilin et al., 2013). In our study area, we found that differences in the economic trends associated to tourism between regions affected the collaborative structure among the stockmen. structure is characterized by strong bounds and highly connected groups, the

454 development of ski resorts outside that region has caused stockmen near those resorts to turn to snow tourism-related services and the entrance of non-local stockmen, who have 
not created yet strong cooperative bounds with local stockmen. This separation between

457 local and non-local stockmen can result in the loss of traditional ecological knowledge

458 in the area leading to an inefficient exploitation of pastures, which might reduce their

459 ecological and pastoral value. Thus, preserving the local knowledge would require

460 strengthening the bounds between local and non-local stockmen. In our study area,

461 economic gain appeared as the most important driver of collaborations. Specifically,

462 subsidy-oriented partnerships included the highest number of collaborative links, and

463 were the only partnerships which connected stockmen from both regions. This suggests

464 that economic profit is mandatory to involve local populations. Therefore, including

465 local and non-local stockmen in the same subsidy partnerships seems the most efficient

466 strategy to strengthen the collaboration between them. This way, local knowledge

467 would be more easily transmitted to all stockmen shepherding in the area, helping to

468 preserve traditional ecological knowledge and improving the sustainable use of

469 mountain pastures.

470

471 Acknowledgements

472 The study was made possible by the financial support of projects FW7

473 ENV.2009.2.1.3.2 from European Community, and 125/2010 from Organismo

474 Autónomo de Parques Nacionales of Ministerio de Agricultura, Alimentación y Medio

475 Ambiente. We are grateful to Javier Nocito, Javier Sardaña and Francisco Allué, and all

476 the stockmen of the study area for helping with the fieldwork. We also thank Bruce

477 McWhirter for helping with the writing, and the editor and three anonymous reviewers

478 for their helpful comments. 
Bibliography

481

482

483

484

485

486

487

488

489

490

491

492

493

494

495

496

497

498

499

500

501

502

503

504

505

Alados, C.L., Errea, P., Gartzia, M., Saiz, H., Escós, J., 2014. Positive and Negative Feedbacks and Free-Scale Pattern Distribution in Rural-Population Dynamics. PLOS ONE 9, e114561. doi:10.1371/journal.pone.0114561

Aldrich, H., 1999. Organizations evolving. Sage.

Axelrod, R., 1997. The dissemination of culture a model with local convergence and global polarization. J. Confl. Resolut. 41, 203-226.

Barnes-Mauthe, M., Arita, S., Allen, S.D., Gray, S.A., Leung, P., 2013. The Influence of Ethnic Diversity on Social Network Structure in a Common-Pool Resource System: Implications for Collaborative Management. Ecol. Soc. 18. doi:10.5751/ES-05295180123

Beilin, R., Reichelt, N.T., King, B.J., Long, A., Cam, S., 2013. Transition Landscapes and Social Networks: Examining On-Gound Community Resilience and its Implications for Policy Settings in Multiscalar Systems. Ecol. Soc. 18. doi:10.5751/ES-05360-180230

Berkes, F., Colding, J., Folke, C., 2008. Navigating Social-Ecological Systems: Building Resilience for Complexity and Change. Cambridge University Press.

Berkes, F., Folke, C., Colding, J., 2000. Linking social and ecological systems: management practices and social mechanisms for building resilience. Cambridge University Press.

Berkes, F., Ross, H., 2013. Community Resilience: Toward an Integrated Approach. Soc. Nat. Resour. 26, 5-20. doi:10.1080/08941920.2012.736605

Bernués, A., Olaizola, A., Corcoran, K., 2003. Extrinsic attributes of red meat as indicators of quality in Europe: an application for market segmentation. Food Qual. Prefer. 14, 265276. doi:10.1016/S0950-3293(02)00085-X

Bodin, Ö., Crona, B.I., 2009. The role of social networks in natural resource governance: What relational patterns make a difference? Glob. Environ. Change 19, 366-374. doi:10.1016/j.gloenvcha.2009.05.002 
Borgatti, S.P., Halgin, D.S., 2011. Analyzing affiliation networks. Sage Handb. Soc. Netw. Anal. 417-433.

Caballero, R., Fernandez-Gonzalez, F., Badia, R.P., Molle, G., Roggero, P.P., Bagella, S., Papanastasis, V.P., Fotiadis, G., Sidiropoulou, A., Ispikoudis, I., others, 2011. Grazing systems and biodiversity in Mediterranean areas: Spain, Italy and Greece. Pastos 39, 9 154.

Confederación de Cooperativas Agrarias de España, 2002. Aportación de CCAE sobre cooperativismo. El Libro Blanco Agric. Desarro. Rural.

Consejo de las Comunidades Europeas, 1992. Directiva 92/43/CEE del Consejo, de 21 de mayo de 1992, relativa a la conservación de los hábitats naturales y de la fauna y flora silvestres. D. Of. Las Comunidades Eur. 7-50.

Consejo Europeo, 2005a. Reglamento (CE) 1290/2005 del Consejo, de 21 de junio de 2005, sobre la financiación de la politica agrícola común.

Consejo Europeo, 2005b. Reglamento (CE) 1290/2005 del Consejo, de 21 de junio de 2005, sobre la financiación de la política agrícola común. Doc. Of. Unión Eur.

Crane, T.A., 2010. Of models and meanings: cultural resilience in social-ecological systems. Ecol. Soc. 15, 19.

Daumas, M., 1976. La vie rurale dans le Haut Aragón Orientale. Institutos de estudios oscenses y de geografia aplicada.

Davidson, D.J., 2010. The Applicability of the Concept of Resilience to Social Systems: Some Sources of Optimism and Nagging Doubts. Soc. Nat. Resour. 23, 1135-1149. doi:10.1080/08941921003652940

Feld, S.L., 1981. The Focused Organization of Social Ties. Am. J. Sociol. 86, 1015-1035.

Fernández-Giménez, M., 2015. “A shepherd has to invent”: Poetic analysis of social-ecological change in the cultural landscape of the central Spanish Pyrenees. Ecol. Soc. 20.

Fernández-Giménez, M.E., Fillat, F., 2012. Pyrenean Pastoralists’ Ecological Knowledge: Documentation and Application to Natural Resource Management and Adaptation. Hum. Ecol. 40, 287-300. doi:10.1007/s10745-012-9463-x 
Fiksel, J., 2006. Sustainability and resilience: toward a systems approach. Sustain. Sci. Pract. Policy 2, 14-21.

Fillat, F., Aguirre, A.J., i Fabré, F.P., Fondevilla, C., 2012. La conservación de la montaña alpina y el bienestar humano. Ambienta Rev. Minist. Medio Ambiente 116-132.

Frank, D.A., McNaughton, S.J., Tracy, B.F., 1998. The ecology of the earth's grazing ecosystems. BioScience 513-521.

García-Martínez, A., Olaizola, A., Bernués, A., 2009. Trajectories of evolution and drivers of change in European mountain cattle farming systems. animal 3, 152-165. doi:10.1017/S1751731108003297

García-Ruiz, J.M., Lasanta, T., Ruiz-Flano, P., Ortigosa, L., White, S., González, C., Martí, C., 1996. Land-use changes and sustainable development in mountain areas: a case study in the Spanish Pyrenees. Landsc. Ecol. 11, 267-277. doi:10.1007/BF02059854

Gartzia, M., Alados, C.L., Pérez-Cabello, F., 2014. Assessment of the effects of biophysical and anthropogenic factors on woody plant encroachment in dense and sparse mountain grasslands based on remote sensing data. Prog. Phys. Geogr. 38, 201-217. doi:10.1177/0309133314524429

Gartzia, M., Fillat, F., Pérez-Cabello, F., Alados, C.L., 2016a. Influence of Agropastoral System Components on Mountain Grassland Vulnerability Estimated by Connectivity Loss. PLOS ONE 11, e0155193. doi:10.1371/journal.pone.0155193

Gartzia, M., Pérez-Cabello, F., Bueno, C.G., Alados, C.L., 2016b. Physiognomic and physiologic changes in mountain grasslands in response to environmental and anthropogenic factors. Appl. Geogr. 66, 1-11. doi:10.1016/j.apgeog.2015.11.007

Gasson, R., Errington, A.J., others, 1993. The farm family business. Cab International.

Gellrich, M., Baur, P., Koch, B., Zimmermann, N.E., 2007. Agricultural land abandonment and natural forest re-growth in the Swiss mountains: A spatially explicit economic analysis. Agric. Ecosyst. Environ. 118, 93-108. doi:10.1016/j.agee.2006.05.001

Gobierno de España, 2007. Ley 5/2007, de 3 de abril, de la Red de Parques Nacionales. Bol. Of. Estado. 
Granovetter, M.S., 1973. The strength of weak ties. Am. J. Sociol. 1360-1380.

563 Hassanein, N., Kloppenburg, J.R., 1995. Where the Grass Grows Again: Knowledge Exchange

564 in the Sustainable Agriculture Movement1. Rural Sociol. 60, 721-740.

565 Holling, C.S., 2001. Understanding the complexity of economic, ecological, and social systems. $566 \quad$ Ecosystems 4, 390-405.

567 Hopwood, B., Mellor, M., O’Brien, G., 2005. Sustainable development: mapping different $568 \quad$ approaches. Sustain. Dev. 13, 38-52.

569 Huber, U.M., Bugmann, H.K., Reasoner, M.A., 2006. Global change and mountain regions: an $570 \quad$ overview of current knowledge. Springer.

571 Isaac, M.E., Erickson, B.H., Quashie-Sam, S.J., Timmer, V.R., 2007. Transfer of knowledge on 572 agroforestry management practices: the structure of farmer advice networks. Ecol. Soc. $573 \quad 12,32$.

574 Janssen, M.A., Bodin, Ö., Anderies, J.M., Elmqvist, T., Ernstson, H., McAllister, R.R., Olsson, 575 P., Ryan, P., 2006. Toward a network perspective of the study of resilience in social576 ecological systems. Ecol. Soc. 11, 15.

577 Jodha, N.S., Banskota, M., Partap, T., others, 1992. Sustainable mountain agriculture. Volume 578 1: perspectives and issues. Volume 2: farmer's strategies and innovative approaches. $579 \quad$ Intermediate Technology Publications.

580 Kohler, F., Gillet, F., Gobat, J.-M., Buttler, A., 2004. Seasonal vegetation changes in mountain 581 pastures due to simulated effects of cattle grazing. J. Veg. Sci. 15, 143-150.

582 Komac, B., Alados, C.L., Camarero, J.J., 2011. Influence of topography on the colonization of 583 subalpine grasslands by the thorny cushion dwarf Echinospartum horridum. Arct.

$584 \quad$ Antarct. Alp. Res. 43, 601-611.

585 Korner, C., Spehn, E., 2002. Mountain biodiversity: a global assessment. CRC.

586 Krackhardt, D., Stern, R.N., 1988. Informal networks and organizational crises: An 587 experimental simulation. Soc. Psychol. Q. 123-140.

588 Lasanta, T., Vicente-Serrano, S.M., 2007. Cambios en la cubierta vegetal en el Pirineo aragonés $589 \quad$ en los últimos 50 años. Pirineos 162, 125-154. 
590

591

592

593

594

595

596

597

598

599

600

601

602

603

604

605

606

607

608

609

610

611

612

613

614

615

Lasanta, T., Vicente-Serrano, S.M., 2007. Cambios en la cubierta vegetal en el Pirineo aragonés en los últimos 50 años. Pirineos 162, 125-154.

Lomolino, M., 2001. Elevation gradients of species-density: historical and prospective views. Glob. Ecol. Biogeogr. 10, 3-13.

Marín-Yaseli, M., Lasanta, T.L., 2003. Competing for meadows: A case study on tourism and livestock farming in the Spanish Pyrenees. Mt. Res. Dev. 23, 169-176.

Mather, A., 2001. The transition from deforestation to reforestation in Europe. Agric. Technol. Trop. Deforestation 35-52.

McPherson, M., Smith-Lovin, L., Cook, J.M., 2001. Birds of a feather: Homophily in social networks. Annu. Rev. Sociol. 415-444.

Milchunas, D.G., Lauenroth, W.K., 1993. Quantitative effects of grazing on vegetation and soils over a global range of environments. Ecol. Monogr. 63, 327-366.

Millenium Ecosystems Assessment, 2005. Ecosystems and human well-being. Island Press Washington, DC.

Newman, M.E., 2006a. Modularity and community structure in networks. Proc. Natl. Acad. Sci. 103, 8577-8582. doi:10.1073/pnas.0601602103

Newman, M.E., 2006b. Modularity and community structure in networks. Proc. Natl. Acad. Sci. $103,8577-8582$.

Olsson, P., Folke, C., Berkes, F., 2004. Adaptive Comanagement for Building Resilience in Social-Ecological Systems. Environ. Manage. 34, 75-90. doi:10.1007/s00267-0030101-7.

Ostrom, E., 2009. A General Framework for Analyzing Sustainability of Social-Ecological Systems. Science 325, 419-422. doi:10.1126/science.1172133

Oteros-Rozas, E., Martín-López, B., González, J.A., Plieninger, T., López, C.A., Montes, C., 2013. Socio-cultural valuation of ecosystem services in a transhumance socialecological network. Reg. Environ. Change 1-21. 
Pinilla, V., Ayuda, M.-I., Sáez, L.-A., 2008. Rural depopulation and the migration turnaround in Mediterranean Western Europe: a case study of Aragon. J. Rural Community Dev. 3, 2008.

Plieninger, T., 2006. Habitat loss, Fragmentation, and Alteration - Quantifying the Impactof Land-use Changes on a Spanish Dehesa Landscape by Use of Aerial Photography and GIS. Landsc. Ecol. 21, 91-105. doi:10.1007/s10980-005-8294-1

R Development Core TeamTeam, 2014. R: A language and environment for statistical computing. R Foundation for Statistical Computing, Vienna, Austria, 2012. ISBN 3900051-07-0.

Riedel, J.L., Casasús, I., Bernués, A., 2007. Sheep farming intensification and utilization of natural resources in a Mediterranean pastoral agro-ecosystem. Livest. Sci. 111, 153163. doi:10.1016/j.livsci.2006.12.013

Rockström, J., Steffen, W., Noone, K., Persson, \AAsa, Chapin, F.S., Lambin, E.F., Lenton, T.M., Scheffer, M., Folke, C., Schellnhuber, H.J., others, 2009. A safe operating space for humanity. Nature 461, 472-475.

Rössler, M., 2006. World Heritage cultural landscapes: A UNESCO flagship programme 1992 2006. Landsc. Res. 31, 333-353. doi:10.1080/01426390601004210

Ruiz, M., Ruiz, J., 1986. Ecological history of transhumance in Spain. Biol. Conserv. 37, 73-86.

Sal, A.G., Lorente, I., 2004. The present status and ecological consequences of transhumance in Spain, in: Transhumance and Biodiversity in European Mountains. pp. 233-248.

Sala, O.E., Chapin, F.S., Armesto, J.J., Berlow, E., Bloomfield, J., Dirzo, R., Huber-Sanwald, E., Huenneke, L.F., Jackson, R.B., Kinzig, A., others, 2000. Global biodiversity scenarios for the year 2100. science 287, 1770-1774.

Tompkins, E.L., Adger, Wn., 2004. Does adaptive management of natural resources enhance resilience to climate change? Ecol. Soc. 9, 10.

Van Auken, O., 2000. Shrub invasions of North American semiarid grasslands. Annu. Rev. Ecol. Syst. 197-215. 
643 Veysset, P., Bebin, D., Lherm, M., 2005. Adaptation to Agenda 2000 (CAP reform) and 644 optimisation of the farming system of French suckler cattle farms in the Charolais area: 645 a model-based study. Agric. Syst. 83, 179-202. doi:10.1016/j.agsy.2004.03.006

646 Vitousek, P.M., 1994. Beyond global warming: ecology and global change. Ecology 75, 1861$647 \quad 1876$

648 Vitousek, P.M., D’Antonio, C.M., Loope, L.L., Rejmanek, M., Westbrooks, R., 1997.

649 Introduced species: a significant component of human-caused global change. N. Z. J.

$650 \quad$ Ecol. 21, 1-16.

651 Young, O.R., Berkhout, F., Gallopin, G.C., Janssen, M.A., Ostrom, E., van der Leeuw, S., 2006.

652 The globalization of socio-ecological systems: An agenda for scientific research. Glob.

$653 \quad$ Environ. Change 16, 304-316.

654 Zervas, G., 1998. Quantifying and optimizing grazing regimes in Greek mountain systems. J.

$655 \quad$ Appl. Ecol. 35, 983-986.

656 

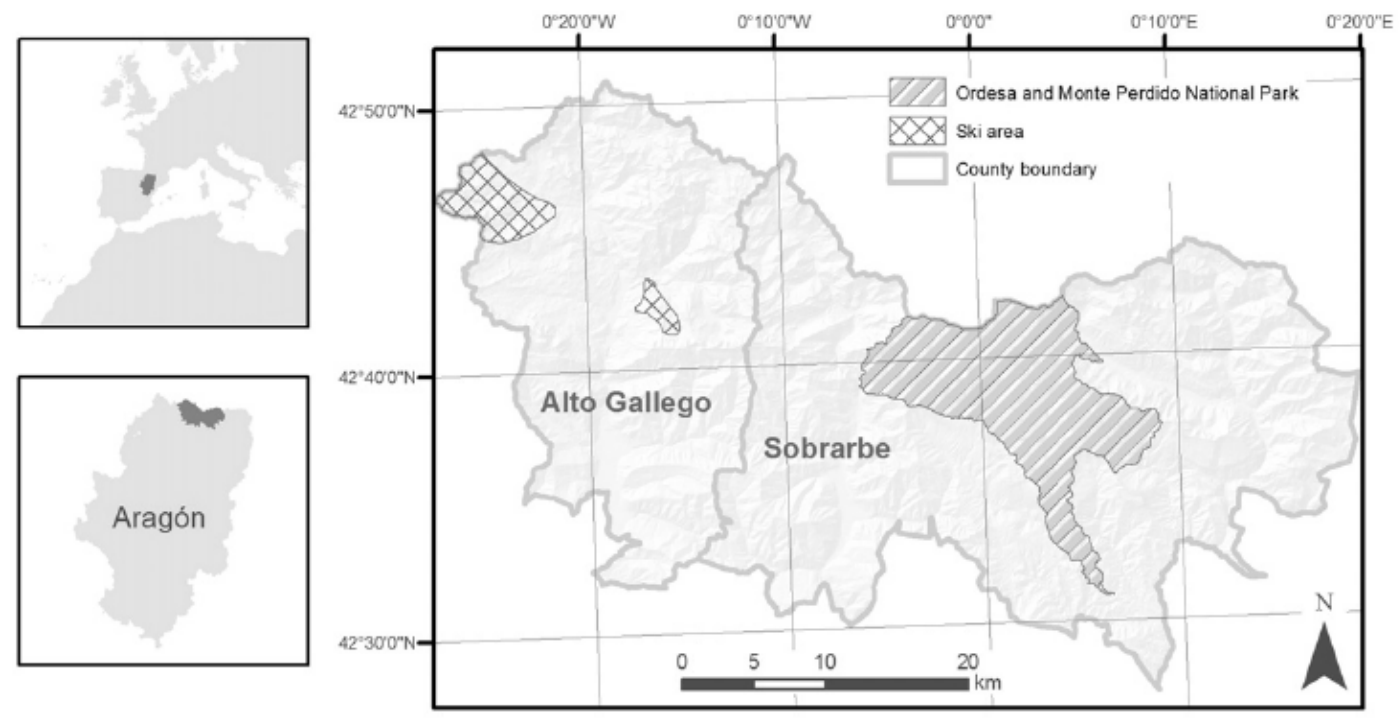

657

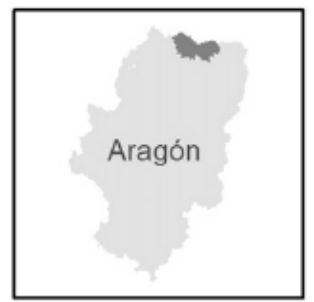

658 Figure 1. Study area in the Spanish Central Pyrenees. Study was conducted in the north

659 side of the regional county of Aragón, Spain. Two study regions are adjacent, but one is

660 strongly influenced by Ordesa-Monte Perdido National Park (NP, Sobrarbe, right), and

661 the other is influenced by the presence of ski resorts (SKI, Alto Gallego, left).

662 Highlighted parts in the map represent the area covered by the Ordesa-Monte Perdido

663 National Park in Sobrarbe, and the area covered by ski resorts in Alto-Gállego. 


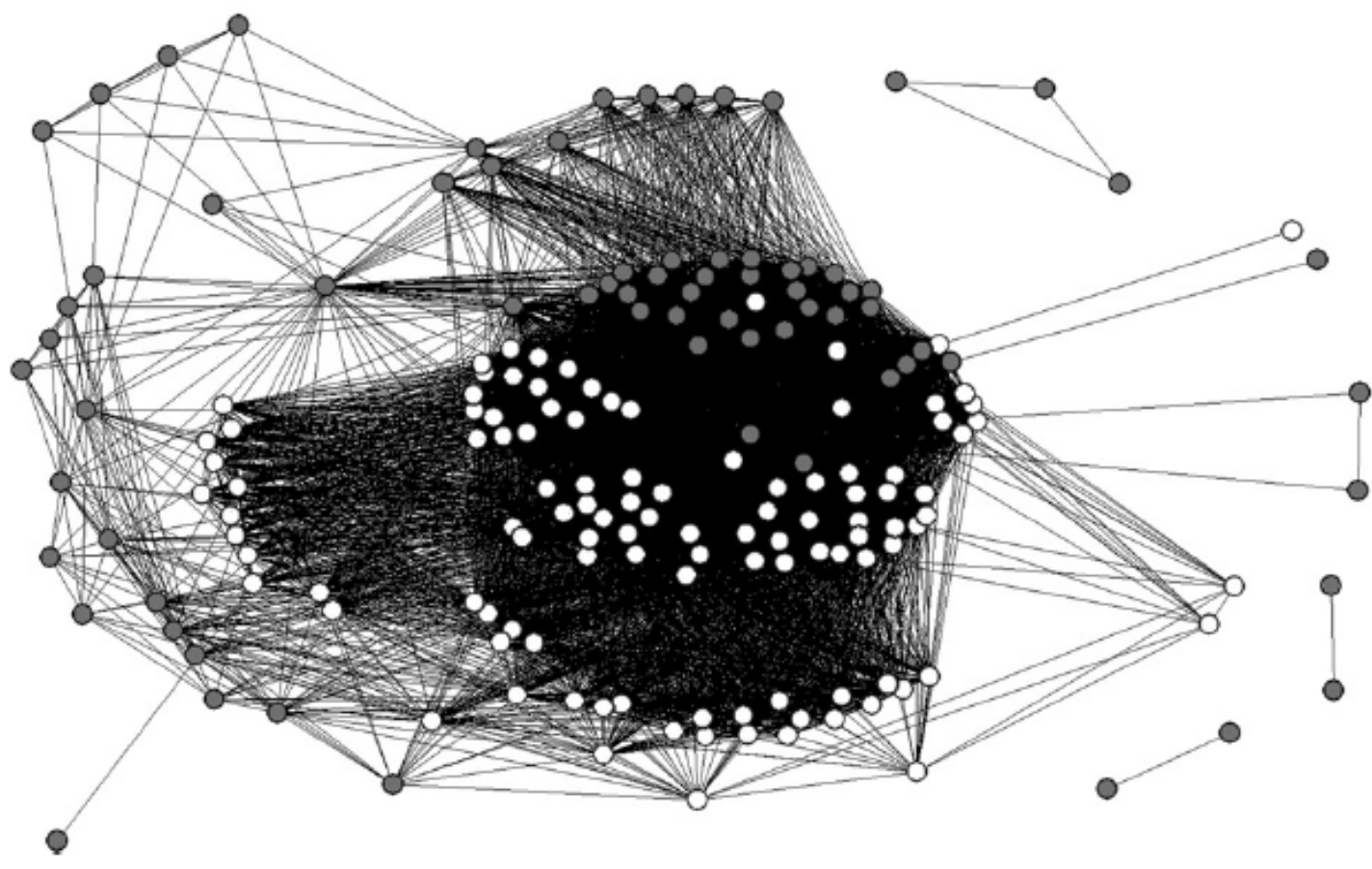

666 Figure 2. Stockmen Collaborative Network in Spanish Central Pyrenees. White nodes

667 are stockmen in NP and grey nodes stockmen in SKI. Links are drawn under the

668 assumption that all have the same strength $\left(l_{i j}=1\right.$ if $\left.l_{i j} \geq 1\right)$. Isolated stockmen

669 (stockmen which did not connect to any other) are not included (9 nodes). 

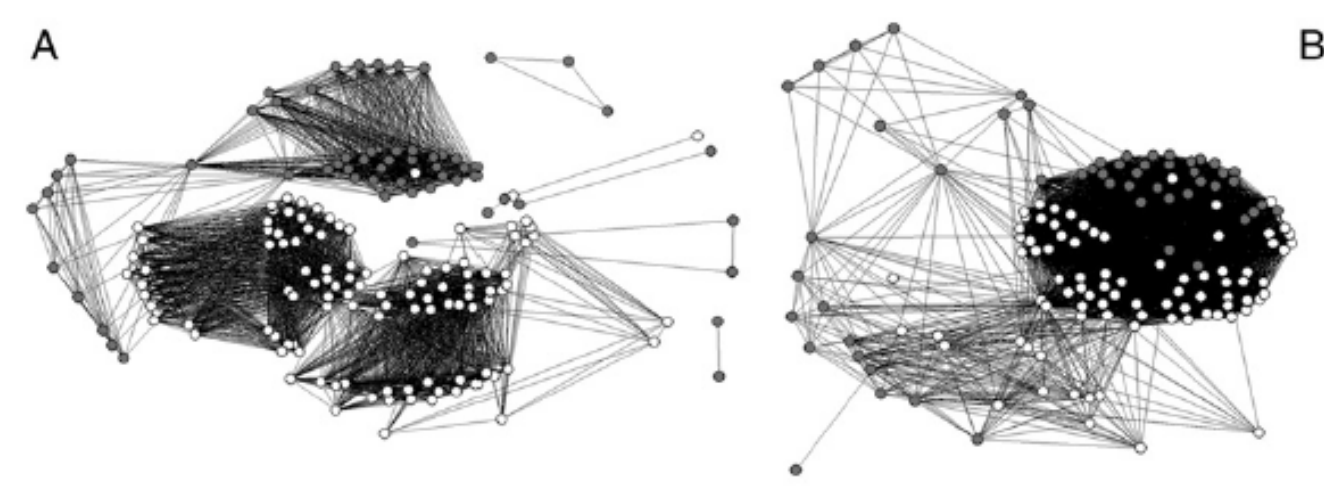

B

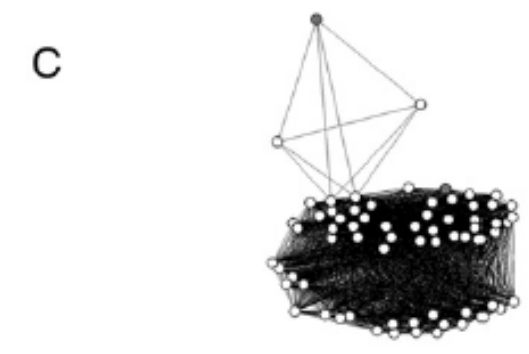

671

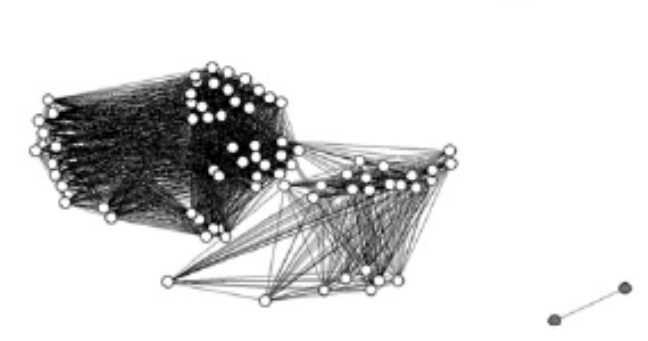

672 Figure 3. Stockmen Collaborative Networks in the Spanish Central Pyrenees depending

673 on the type of association. A) SCN for health associations; B) SCN for subsidy

674 associations; C) SCN for cooperative associations; D) SCN for local associations.

675 White nodes are stockmen in NP and grey nodes stockmen in SKI. Links are drawn

676 under the assumption that all have the same strength $\left(l_{i j}=1\right.$ if $\left.l_{i j} \geq 1\right)$. Isolated stockmen

677 (stockmen who did not connect to any other) are not represented (9 nodes). 

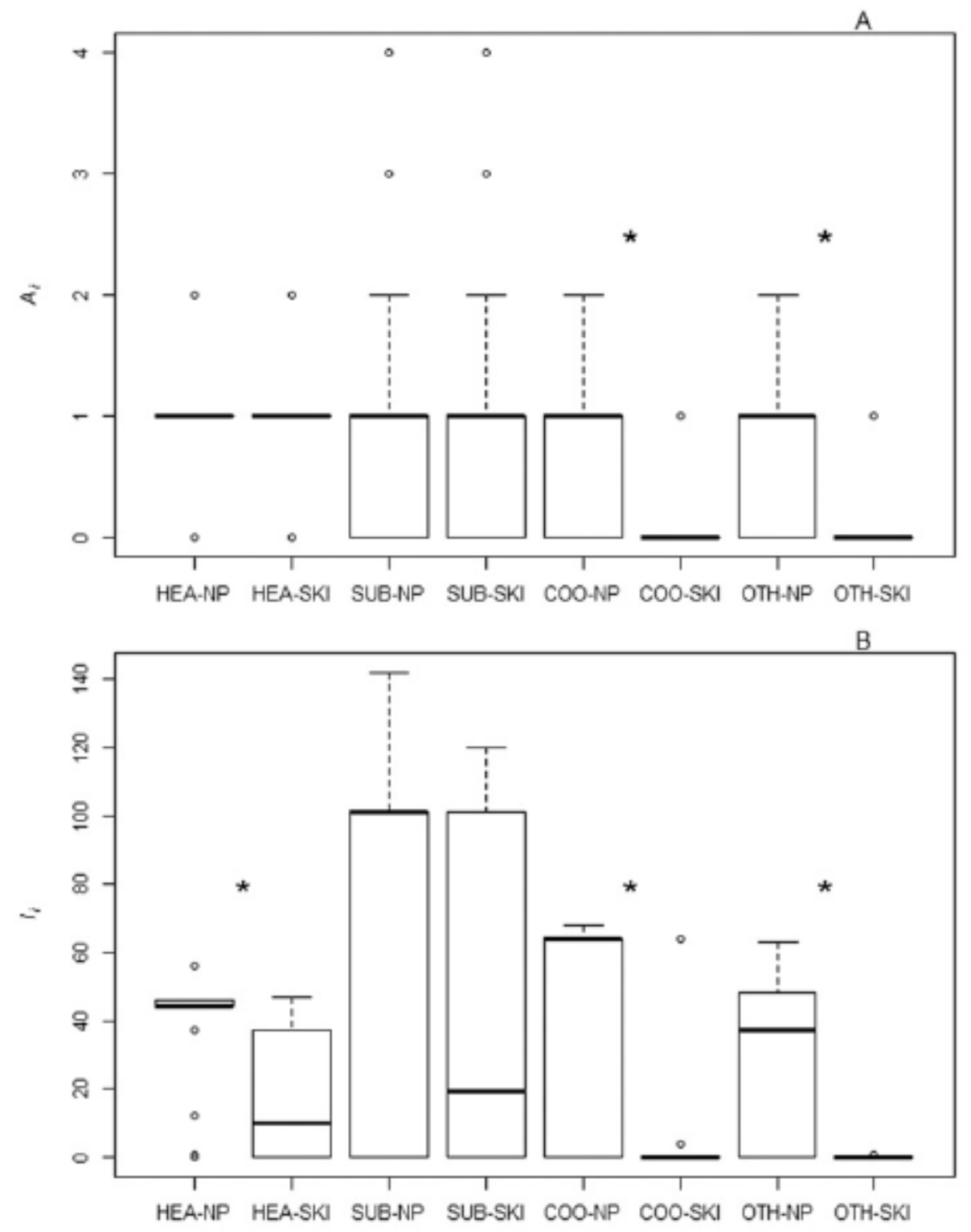

678

679 Figure 4. Effect of type of associations and region in the number of associations per 680 stockbreeder and links per stockbreeder in the Spanish Central Pyrenees. A) $A_{i}$, number 681 of associations per stockbreeder; B) $l_{i}$, number of links per stockbreeder. HEA, health682 based associations; SUB, subsidy-based associations; COO, cooperative-based 683 associations; OTH, others associations; NP, region that included a National Park; SKI, 684 region that included ski resorts. * indicates significant differences between regions for a 685 given type of associations (based on a post-hoc Tukey test). 
688 Table 1. Current characteristics of the two study regions in the Spanish Central 689 Pyrenees.

\begin{tabular}{lll}
\hline Variable & Sobrarbe (NP) & Alto Gállego (SKI) \\
\hline Area & $893.62 \mathrm{~km}^{2}$ & $490.02 \mathrm{~km}^{2}$ \\
Population & $2.27 \mathrm{hab} / \mathrm{km}^{2}$ & $8.44 \mathrm{hab} / \mathrm{km}^{2}$ \\
Agro-pastoral activity & $14 \%(-35 \%)$ & $3 \%(-29 \%)$ \\
Touristic activity & $74 \%(+38 \%)$ & $87 \%(+49 \%)$ \\
Campsites and rural houses & 5138 places & 1377 places \\
Hotels and apartments & 2196 places & 4126 places \\
New buildings & 1041 houses & 11317 houses
\end{tabular}

690 Area, surface of the region ; Population, density of inhabitants; Agro-pastoral activity, 691 proportion of the population mainly identified as working in agro-pastoral activities;

692 Services activity, proportion of the population mainly identified as working in services 693 activities (values in parentheses represent the change in proportion of the population 694 identified as working in each activity since 1981); Campsites and rural houses, number 695 of touristic places available in campsites and rural houses; Hotels and apartments, 696 number of touristic places available in hotels and apartments; New buildings, number of 697 new houses constructed since 1980. Sobrarbe region is under the influence of a National 698 Park (NP); while Alto Gállego region is under the influence of Ski resorts (SKI). All the 699 data were obtained from Instituto Aragonés de Estadística and Instituto Nacional de 700 Estadística and represent year 2010. 
702 Table 2. Partnerships of stockmen in the study area in the Spanish Central Pyrenees.

\begin{tabular}{llll}
\hline Partnership & Number & Objective & Example of activity \\
\hline Health & 15 & Maintain health & Periodically perform mandatory \\
(HEA) & & standards of the animals & sanitary tests to animals (health \\
& 12 & Obtain funds for pastoral & Help stockmen to obtain quality \\
Subsidy & & activities & labels (protected breed associations) \\
(SUB) & & Improve marketing of & Coordinate and advises stockmen \\
Cooperatives & 4 & livestock products & business (agro-pastoral cooperatives) \\
(COO) & & All other stockmen & Organize country markets (groups of \\
Others & 5 & associations & stockmen from the same town) \\
(OTH) & & &
\end{tabular}

703 Partnership, type of partnership according to the interest pursued by its members;

704 Number, number of associations of each type in the whole study area; Objective, duty of

705 the partnership; Example of activity, actions taken by partnerships which directly

706 involve stockmen members. 
Table 3. Definitions of indices used in stockmen collaboration networks.

\begin{tabular}{lll}
\hline Index & Definition & Interpretation \\
\hline Isolation $($ Iso $)$ & Number of nodes with no links. & High values indicate that many stockmen do \\
Density $(D)$ & Mean number of links per node. & High values indicate that stockmen highly \\
& & collaborate with others. \\
Modularity $(Q)$ & Presence in the network of subgroups & High values indicate that stockmen form \\
& composed by highly connected nodes. & groups inside which collaboration is strong. \\
Krackhardt & Ratio between links from nodes in & Positive values indicate that stockmen \\
Ratio $(E / I)$ & different and links from nodes in the & principally collaborate with stockmen from \\
& same network. & other region, while negative values indicate
\end{tabular}


Table 4. Characteristics of the stockmen collaboration networks in study area in the

709 Spanish Central Pyrenees.

\begin{tabular}{lccccccc}
\hline Region & $S$ & $P$ & P/breed & Iso/S & $D$ & $Q$ & $E / I$ \\
\hline Total study & 194 & 36 & 2.63 & 0.05 & 124.7 & 0.27 & -0.79 \\
area (TSA) & & & & & & \\
Sobrarbe & 81 & 21 & 1.88 & 0.02 & 145.2 & 0.25 & \\
(NP) & & & & & & & \\
Alto Gállego & 113 & 26 & 3.69 & 0.1 & 32.97 & 0.12 & \\
(SKI) & & & & & & \\
\hline
\end{tabular}

$710 S$, number of stockmen; $P$, number of partnerships that stockmen in the network

711 belonged to; P/breed, mean number of partnerships which a stockbreeder belonged to;

712 Iso/S, proportion of stockmen without links; $D$, density; $Q$, modularity; E/I, Krackhardt

713 Ratio. Sobrarbe region is under the influence of a National Park (NP); while Alto

714 Gállego region is under the influence of Ski resorts (SKI). 
716 Table 5. Indices for Stockmen Collaboration Networks in the study areas of the Spanish 717 Central Pyrenees.

\begin{tabular}{llllll}
\hline Region & Network & Iso & $D$ & $Q$ & $E / I$ \\
\hline Total study & real & $\mathbf{9}$ & - & $\mathbf{0 . 2 7}$ & $\mathbf{- 0 . 7 9}$ \\
area (TSA) & sim & $6.39(0.61)$ & - & $0.11(0.02)$ & $-0.18(0.02)$ \\
\hline Sobrarbe (NP) & real & 2 & $\mathbf{1 4 5 . 2}$ & $\mathbf{0 . 2 5}$ & - \\
& sim & $2.08(0.28)$ & $107.62(0.29)$ & $0.08(0.02)$ & - \\
\hline Alto Gállego & real & $\mathbf{8}$ & $\mathbf{3 2 . 9 7}$ & $\mathbf{0 . 1 2}$ & - \\
(SKI) & sim & $5.57(1.2)$ & $25.23(0.13)$ & $0.22(0.05)$ & -
\end{tabular}

718 Iso, stockmen without links; $D$, density; $Q$, modularity; E/I, E/I Ratio. Sobrarbe region

719 is under the influence of a National Park (NP); while Alto Gállego region is under the 720 influence of Ski resorts (SKI). Sim is the mean (standard deviation) of the index based

721 on 1000 simulations. Indices were significantly different from simulated ones (indicated

722 in bold) if they were more than 2 standard deviations above or below the mean values

723 from the simulations. $D$ was calculated for the two regions, individually, because the

724 null model fixed $L$ in the network, and $E / I$ was only calculated for the two regions

725 combined because it included the links with and between regions. 
727 Table 6. GLM and GLMM for the number of partnerships per stockbreeder and links

728 per stockbreeder in the Spanish Central Pyrenees.

\begin{tabular}{|c|c|c|c|c|c|c|c|}
\hline \multirow[t]{2}{*}{ Level } & Response & Explanatory & $\overline{D f}$ & $S S E$ & $M S E$ & $F-$ & \multirow[t]{2}{*}{$p$-value } \\
\hline & variable & variable & & & & value & \\
\hline \multirow[t]{4}{*}{ All data } & $A_{i}$ & Region & 1 & 123.6 & 123.6 & 88.06 & \multirow[t]{2}{*}{$<0.001 * * *$} \\
\hline & & Residuals & 192 & 269.4 & 1.4 & & \\
\hline & \multirow[t]{2}{*}{$L_{i}$} & Region & 1 & 503569 & 503569 & 107.5 & \multirow[t]{2}{*}{$<0.001 * * *$} \\
\hline & & Residuals & 192 & 899054 & 4683 & & \\
\hline Type of & $\overline{A_{i}}$ & Region & 1 & 30.89 & 30.89 & 88.06 & $<0.001 * * *$ \\
\hline
\end{tabular}

\begin{tabular}{lllllll} 
Partnership & 3 & 44.21 & 14.737 & 51.93 & $<0.001 * * *$ \\
Region x & 3 & 14.57 & 4.857 & 17.11 & $<0.001^{* * * *}$ \\
Partnership & & & & & \\
Residuals & 576 & 163.47 & 0.28 & & \\
\hline$L_{i}$ & Region & 1 & 125892 & 125892 & 107.5 & $<0.001^{* * *}$ \\
& Partnership & 3 & 192.96 & 64321 & 82.77 & $<0.001 * * *$ \\
& Region x & 3 & 75.98 & 2533 & 3.26 & $0.021^{*}$ \\
& Partnership & & & & &
\end{tabular}

Residuals $\quad 576 \quad 447638 \quad 777$

$729 A i$, number of partnerships per stockman; $L i$, number of links per stockman. Statistically

730 significant variables are indicated in bold. * $p<0.05 ; * * p<0.01 ; * * * p<0.001$. 